\title{
Pengambilan Keputusan Pemilihan Sekolah Dasar Islam Menggunakan Metode SAW dan FMADM di Pangkalpinang
}

\author{
Harrizki Arie Pradana ${ }^{[1]^{*}}$, Fitriyani ${ }^{[2]}$, Marisa ${ }^{[3]}$ \\ Program Studi Teknik Informatika ${ }^{[1],[3]}$ Program Studi Sistem Informasi ${ }^{[2]}$ \\ STMIK Atma Luhur ${ }^{[1],[2]}$ STMIK Bani Saleh ${ }^{[3]}$ \\ Jl. Jend. Sudirman, Selindung, Pangkalpinang, Bangka Belitung, Indonesia \\ harrizkiariep@atmaluhur.ac.id ${ }^{[1],}$ bilalzakwan12@yahoo.com ${ }^{[2]}$, ichaich28@yahoo.com ${ }^{[3]}$
}

\begin{abstract}
Islamic Elementary Schools are schools that apply the concept of Islamic education based on the Koran and asSunnah. Many parents have the choice to send their children to Islamic schools to explore Islam further. But often parents are confused about making their choices. This is because there are no methods or tools that can be used to determine the chosen primary school. For this reason, a system is designed to determine Islamic Elementary Schools using the Simple Additive weighting (SAW) and Fuzzy Multi-Attribute Decision Making (FMADM) methods. The Simple Additive Weighting (SAW) method is used to rank the available alternatives. Fuzzy MultiAttribute Decision Making (FMADM) method is used to find alternatives from many alternatives with predetermined criteria. The results obtained to state that Qur'an Elementary School is the most recommended in the selection of Islamic Elementary Schools in the City of Pangkalpinang. The results of this study can also be used as a tool for making decisions to recommend Islamic-based elementary schools. The results for SDIT A Insantama scored 0.30, SDIT A At-Tauhid obtained a value of 0.29, SDIT Albina obtained a value of 0.305 , Qur'anic SD was 0.31, and finally, SDIT Al-Qudwah obtained a value of 0.29 .

Keywords-SAW; FMADM; Recommendation
\end{abstract}

Abstrak-Sekolah Dasar Islam pada dasarnya adalah sekolah yang menerapkan konsep pendidikan Islam berdasarkan alQuran dan as-Sunnah. Banyak orang tua memiliki pilihan untuk mengirim anak-anak mereka ke sekolah Islam untuk mengeksplorasi agama Islam lebih lanjut. Tetapi seringkali orang tua bingung untuk menentukan pilihan mereka. Ini karena tidak ada metode atau alat yang dapat digunakan untuk menentukan sekolah dasar pilihan. Untuk itu, dirancang suatu sistem untuk menentukan Sekolah Dasar Islam dengan menggunakan metode Simple Additive weighting (SAW) dan Fuzzy Multi Attribute Decision Making (FMADM). Metode Simple Additive Weighting (SAW) digunakan untuk menentukan peringkat dari alternatif yang tersedia. Metode Fuzzy Multi Attribute Decision Making (FMADM) digunakan untuk menemukan alternatif dari banyak alternatif dengan kriteria yang telah ditentukan. Hasil yang didapatkan menyatakan bahwa SD Qur'an merupakan rekomendasi paling banyak dalam pemilihan Sekolah Dasar Islam di Kota Pangkalpinang. Hasil penelitian ini dapat juga digunakan sebagai alat dalam pengambilan keputusan untuk merekomendasikan Sekolah
Dasar yang berbasis Islam. Hasil untuk SDIT A Insantama memperoleh nilai 0,30, SDIT A At-Tauhid memperoleh nilai 0,29, SDIT Albina memperoleh nilai 0,305, SD Qur'an sebesar 0,31, dan terakhir adalah SDIT Al-Qudwah memperoleh nilai sebesar 0,29 .

\section{Kata Kunci-SAW; FMADM; Recommendation}

\section{PENDAHULUAN}

Sekolah adalah lembaga pendidikan formal yang memegang peranan penting dalam mencapai tujuan pendidikan nasional. Pencapaian tujuan tersebut melalui interaksi pembelajaran dalam lingkungan yang sistematis dan terarah. Sekolah sebagai pusat pendidikan formal lahir dan berkembang dari pemikiran efisiensi dan efektivitas pemberian pendidikan kepada masyarakat [1]. Sekolah dasar merupakan sekolah formal yang pertama bagi anak. Kenyataan ini sangat penting sebagai penanaman nilai dan norma serta sebagai penentu keberhasilan pendidikan selanjutnya. Sekolah dasar termasuk dalam lingkup pendidikan dasar yang kini wajib diikuti warga Indonesia. Sekolah dasar menjadi pondasi awal bagi anak sebagai modal melanjutkan ke jenjang yang lebih tinggi. Komponen sistem pendidikan sekolah dasar secara garis besar terdiri dari siswa sebagai bahan masukan (raw input), komponen instrumental, lingkungan, dan tujuan yang harus dicapai (output) [2].

Pendidikan dasar memiliki peran untuk mengembangkan kemampuan dasar, pengetahuan, dan mengembangkan sikap yang baik pada anak. Pendidikan dasar mengajarkan kemampuan dasar seperti membaca, menulis, dan berhitung. Anak mulai melakukan interaksi dengan dunia baru yang lebih luas dan belajar menjadi makhluk sosial yang sudah dibatasi dengan norma-norma di dalamnya. Anak mengenal dunia organisasi dan kepemimpinan secara sederhana yang nantinya akan dikembangkan pada kehidupan dimasyarakat. Saat ini semakin banyak berkembang lembaga pendidikan khususnya sekolah dasar yang menawarkan suatu bentuk terobosan terbaru di dunia pendidikan khususnya di Indonesia sebagai contoh semakin banyaknya sekolah yang berbasis Islam. Sampai saat ini mampu menarik minat orang tua dalam memilih sekolah dasar yang baik untuk masa depan anaknya. 
Sistem Pendukung Keputusan (SPK) adalah bagian dari sistem informasi berbasis komputer termasuk sistem berbasis pengetahuan atau manajemen pengetahuan yang dipakai untuk mendukung pengambilan keputusan dalam suatu organisasi atau perusahaan [3]. Adapun karakteristik sistem penunjang keputusan [4] adalah mendukung proses pengambilan keputusan yang menitik beratkan pada manajemen dengan persepsi, adanya interface manusia atau mesin dimana manusia sebagai user tetap memegang kontrol proses pengambilan keputusan, mendukung pengambilan keputusan untuk membahas masalah terstruktur, semi terstruktur dan tidak terstruktur, memiliki kapasistas dialog untuk memperoleh informasi sesuai dengan kebutuhan, memiliki subsistem-subsistem yang terintegrasi sedemikian rupa sehingga dapat berfungsi sebagai kesatuan sistem. Adapun SPK juga bisa diklasterisasikan menjadi beberapa tingkatan manajemen, seperti halnya pada gambar 2 menurut [5].

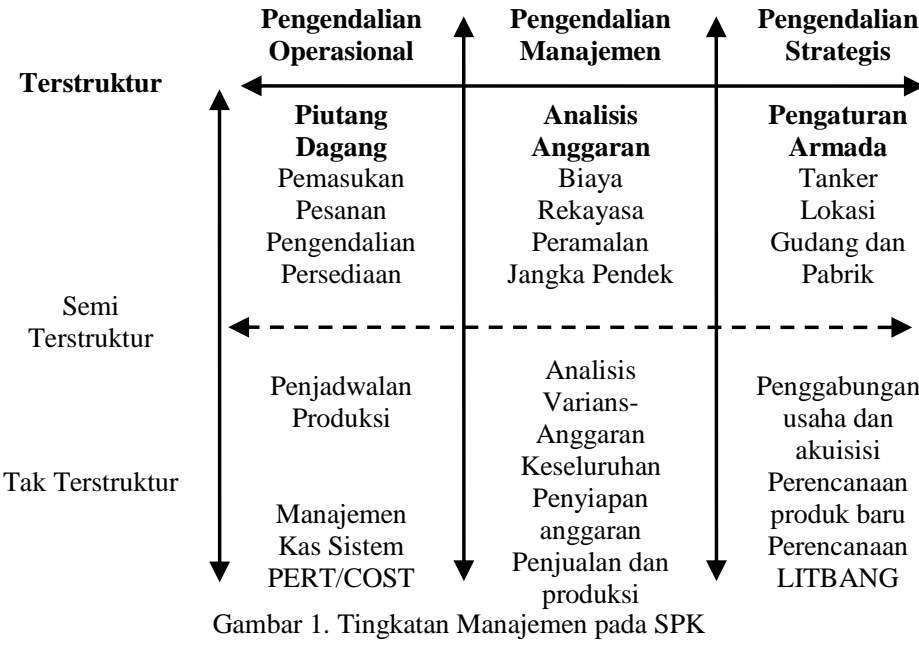

Membutuhkan struktur data komprehensif yang dapat melayani kebutuhan informasi seluruh tahap manajemen [6]. Sekolah dasar merupakan upaya untuk mencerdaskan dan mencetak kehidupan bangsa yang bertaqwa, cinta dan bangga terhadap bangsa dan negara, terampil, kreatif, berbudi pekerti yang santun serta mampu menyelesaikan permasalahan di lingkungannya.

Metode SAW sering juga dikenal istilah metode penjumlahan terbobot. Konsep dasar metode SAW menurut [7] adalah mencari penjumlahan terbobot dari rating kinerja pada setiap alternatif pada semua atribut. Metode SAW membutuhkan proses normalisasi matriks keputusan (X) ke suatu skala yang dapat diperbandingkan dengan semua rating alternatif yang ada [8]. Nilai Vi yang lebih besar mengindikasikan bahwa alternatif Ai, lebih terpilih [9]. Dalam penelitian ini menggunakan FMADM metode SAW. Adapun langkah-langkahnya menurut [10] adalah:

- Menentukan kriteria-kriteria yang akan dijadikan acuan dalam pengambilan keputusan, yaitu $\mathrm{Ci}$.

- Menentukan rating kecocokan setiap alternatif pada setiap kriteria.

Membuat matriks keputusan berdasarkan kriteria (Ci), kemudian melakukan normalisasi matriks berdasarkan persamaan yang disesuaikan dengan jenis atribut (atribut keuntungan ataupun atribut biaya) sehingga diperoleh matriks ternormalisasi R.

Penelitian terdahulu membuat sebuah model DSS (Decision Support System) yang digunakan untuk mengetahui tingkat bahaya asap kendaraan dengan menggunakan FMADM. Hasil dari penelitian ini didapat nilai bahaya tertinggi senilai 0,9757 dari alternatif pengujian V7, sedangkan nilai bahaya tinggi/berbahaya dimulai dari V2 sampai dengan V10 [11]. Metode SAW dan FMADM juga telah digunakan untuk menentukan beasiswa pada SMP 6 Pangkalpinang. Terdapat tiga tipe beasiswa yang diusulkan yakni beasiswa tidak mampu, beasiswa akademik, dan beasiswa non akademik. Beasiswa tidak mampu memiliki tiga kriteria, yakni C1 kepemilikan kartu KIP, C2 surat keterangan tidak mampu, dan $\mathrm{C} 3$ surat keterangan penghasilan orang tua. Beasiswa akademik memiliki kriteria $\mathrm{C} 1$ nilai rata-rata raport dan C2 Juara 1,2,3 kelas. Beasiswa non akademik memiliki tiga kriteria, yakni $\mathrm{C} 1$ jumlah sertifikat juara 1,2,3 tingkat provinsi, C2 jumlah sertifikat juara 1,2,3 tingkat nasional, dan C3 jumlah sertifikat juara 1,2,3 tingkat kabupaten/kota. Hasil penelitian untuk beasiswa tidak mampu adalah alternatif 3 dengan nilai 0,36 . Untuk beasiswa akademik didapat hasil alternatif A2 dan A3 yang memiliki nilai sama, yakni 0,38. Untuk beasiswa non akademik diperoleh pada alternatif 2 dengan nilai 0,2387 [12].

Penentuan beasiswa juga dijadikan persoalan dalam penerapan FMADM dan SAW. Terdapat empat kriteria, yakni C1 IPK, C2 Karya tulis ilmiah, C3 Prestasi yang diunggulkan, dan C4 Bahasa Inggris/Asing. Hasil penelitian didapat nilai tertinggi untuk proses perankingan 3 (V3) dengan nilai 2,750 [13]. Penelitian selanjutnya menerapkan FMADM dengan metode SAW untuk pemilihan calon ketua BEM. Ada tiga kriteria yang digunakan, yakni C1 Frekuensi Mengikuti LDK (Latihan Dasar Kepemimpinan), C2 Prestasi (IPK), dan C3 Visi dan Misi dan Prestasi Non Akademik. Didapat empat kandidat berdasar nilai vector (V) terbesar yakni Bayu (V8) dengan nilai 0,98, Ade Tri (V10) dengan nilai 0,79, Indah Rizky (V6) dengan nilai 0,715, dan Endang Yosfika (V4) dengan nilai 0,6975 [14].

Identifikasi potensi kemiskinan menjadi permasalahan berikutnya yang menggunakan FMADM. Terdapat delapan kriteria, yakni C1 Pekerjaan, C2 Jenis lantai rumah, C3 Tingkat pendidikan, C4 Dinding rumah, C5 Pendapatan per bulan, C6 Fasilitas listrik, C7 Fasilitas buang air besar, dan C8 Sumber air minum. Didapat hasil alternative 6 memiliki jumlah tertinggi 75,25 dan alternative 4 menjadi yang terendah dengan nilai 46,25 [15]

FMADM dengan metode Weighted Product (WP) diterapkan untuk pengambilan keputusan kelayakan penerimaan kredit di BPR. Kriteria yang digunakan ada empat, yakni $\mathrm{C} 1$ besar pinjaman, $\mathrm{C} 2$ jasa pinjaman, $\mathrm{C} 3$ jangka waktu pinjaman, dan $\mathrm{C} 4$ pinjaman ke-. Dari hasil implementasi diketahui bahwa metode WP sangat tepat untuk studi kasus. Dari hasil pengujian, didapat bobot tertinggi yaitu A5 dengan nilai $\mathrm{V}=0,28$ [16]. 
Pemilihan calon kepala daerah juga dijadikan permasalahan yang diselesaikan dengan menggunakan FMADM. Terdapat lima kriteria untuk permasalahan ini, yakni C1 profesional, C2 kemampuan, C3 keberanian, C4 dapat dipercaya, dan C5 banyaknya relasi. Dari tiga calon kepala daerah yang tersedia didapat hasil indeks kecocokan fuzzy pada kandidat nomor 1 dengan nilai 0,2000; 0,4750; 0,7375 . Selanjutnya untuk nilai total integral pada alternatif 1 (A1) memiliki nilai tertinggi untuk setiap nilai derajat keoptimisan $(\alpha=0 ; \alpha=0,5 ; \alpha=1)$ [17].

FMADM yang dikombinasikan dengan K-means clustering digunakan sebagai system pendukung keputusan pemilihan line-up pemain sepak bola dengan contoh pemain dari klub Manchester City. Penelitian ini menggunakan model centeroid. Terdapat delapan kriteria yakni Goal, Assist, Saves, Cleansheet, Kartu Kuning, Kartu merah, Main, dan gol bunuh diri. Dari hasil penerapan, didapat hasil yakni pemain Manchester City dengan nama Sterling memiliki nilai terbaik dengan nilai 625, diikuti oleh Kelechi, Nolito, dan Aguero [18].

\section{METODOLOGI PENELITIAN}

Penerapan metode FMADM pada sistem rekomendasi pengambilan keputusan pemilihan sekolah dasar berbasis Islam di Kota Pangkalpinang menggunakan metode Web Engineering. Web Engineering sendiri adalah memfokuskan diri terhadap aplikasi metodologi, teknik, dan peralatan dalam mendesain dan pengembangan perangkat lunak berbasis Web [19]. Sedangkan menurut [20], aktivitas web engineering bisa dilihat pada gambar 2 .

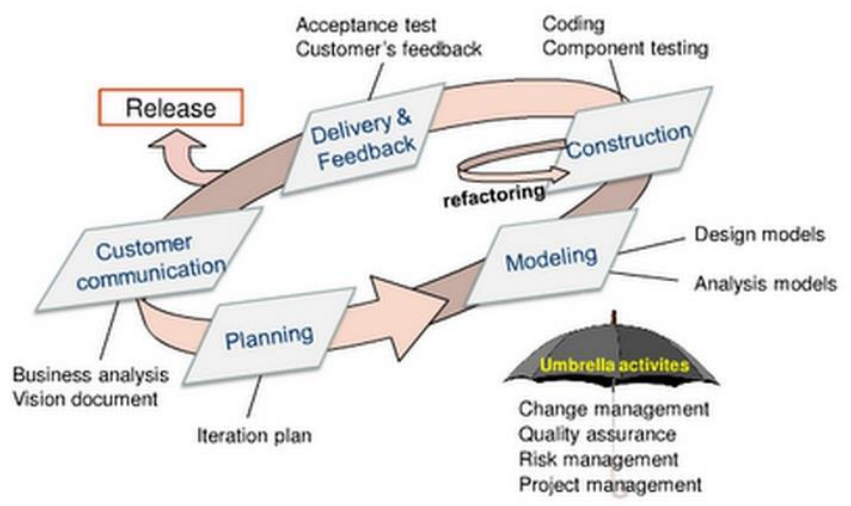

Gambar 2. Aktivitas Metode Web Engineering

Dilihat dari gambar 2, maka bisa disimpulkan untuk melakukan pemilihan sekolah dasar berbasis Islam dengan menggunakan tahapan-tahapan penelitian. Tahapan-tahapan tersebut antara lain adalah melakukan studi literatur guna mengembangkan pengetahuan teori akan kebutuhan penelitian sebelumnya yang kemudian dilanjutkan dengan pengumpulan data agar bisa memproses dan mengetahui hasil dari sistem pendukung keputusan yang digunakan.

Setelah pengumpulan data selesai dilakukan, dilanjutkan dengan pengembangan sistem demi mendapatkan hasil terbaik dari penggunaan sistem pendukung keputusan. Setelah selesainya pembangunan sistem, langkah berikutnya adalah membuat laporan akhir akan hasil yang didapatkan pada penelitian. Proses yang dilakukan dalam mengerjakan penelitian ini meliputi beberapa tahapan yang bila digambarkan seperti pada Gambar 3.

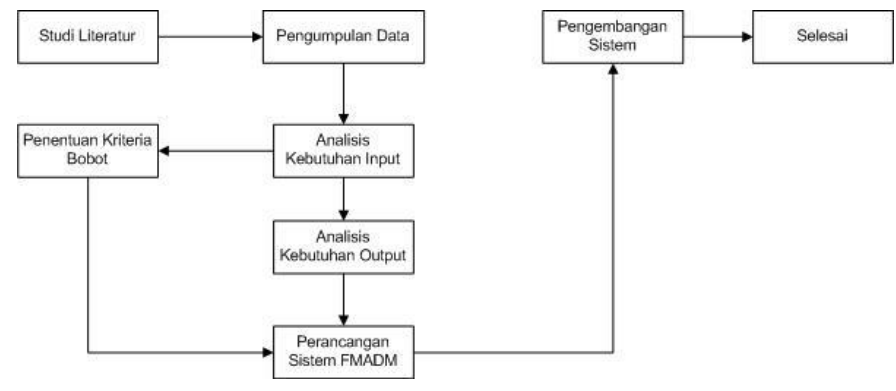

Gambar 3. Tahapan penelitian

Pada gambar 3 jelas diperlukannya suatu penentuan kriteria bobot dalam melakukan analisa kebutuhan inputnya. Hal ini dilakukan untuk mendapatkan nilai dari setiap variabel pengukur supaya valid dan handal dalam menentukan rekomendasi atau pilihan sekolah-sekolah pada Sekolah Dasar Islam Terpadu yang berada di Kota Pangkalpinang, Provinsi Kepulauan Bangka Belitung, sekaligus membantu para calon orang tua siswa dalam memilih pilihan sekolah dasar berbasis Islam yang masih kebingungan dalam menentukan pilihannya.

Adapun gambar 4 menunjukkan karakteristik dan kemampuan dari suatu sistem pendukung keputusan menurut [21].

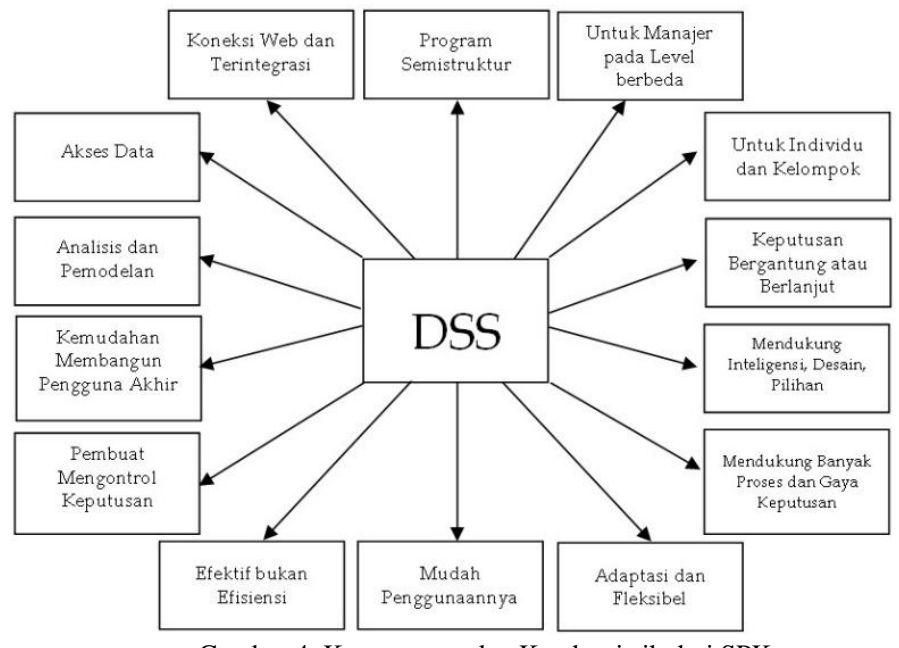

Gambar 4. Kemampuan dan Karakteristik dari SPK

FMADM atau kepanjangan dari Fuzzy Multiple Attribute Decision Making, adalah suatu metode yang digunakan untuk mencari alternatif optimal dari sejumlah alternatif dengan kriteria tertentu [22]. Inti dari FMADM adalah menentukan nilai bobot untuk setiap atribut, kemudian dilanjutkan dengan proses perankingan yang akan menyeleksi alternatif yang sudah diberikan. Pada dasarnya, ada 3 pendekatan untuk mencari nilai bobot atribut menurut [23], yaitu pendekatan subyektif, pendekatan obyektif dan pendekatan integrasi antara subyektif \& obyektif. Masing- masing pendekatan memiliki kelebihan dan kelemahan. Pada pendekatan subyektif, nilai bobot ditentukan berdasarkan subyektifitas 
dari para pengambil keputusan [24], sehingga beberapa faktor dalam proses perankingan alternatif bisa ditentukan secara bebas. Sedangkan pada pendekatan obyektif, nilai bobot dihitung secara matematis sehingga mengabaikan subyektifitas dari pengambil keputusan.

\section{Cara kerja FMADM adalah sebagai berikut [25]:}

- Memberikan nilai setiap alternatif (Ai) pada setiap kriteria $(\mathrm{Cj})$ yang sudah ditentukan, dimana nilai tersebut diperoleh berdasarkan nilai crisp; $i=1,2, \ldots$, $m$ dan $j=1,2, \ldots, n$.

- Memberikan nilai bobot (W) yang juga didapatkan berdasarkan nilai crisp.

- Melakukan normalisasi matriks dengan cara menghitung nilai rating kinerja ternormalisasi (rij) dari alternatif $\mathrm{Ai}$ pada atribut $\mathrm{Cj}$ berdasarkan persamaan yang disesuaikan dengan jenis atribut (atribut keuntungan/benefit=MAKSIMUM atau atribut biaya/cost=MINIMUM). Apabila berupa atribut keuntungan, maka nilai crisp (Xij) dari setiap kolom atribut dibagi dengan nilai crisp MAX (MAX) dari tiap kolom, sedangkan untuk atribut biaya, nilai crisp MIN (MIN) dari tiap kolom atribut dibagi dengan nilai crisp (Xij) setiap kolom.

- Melakukan proses perankingan dengan cara mengalikan matriks ternormalisasi $(\mathrm{R})$ dengan nilai bobot (W).

- Menentukan nilai preferensi untuk setiap alternatif (Vi) dengan cara menjumlahkan hasil kali antara matriks ternormalisasi (R) dengan nilai bobot (W). Nilai Vi yang lebih besar mengindikasikan bahwa alternatif Ai lebih terpilih.

Nilai preferensi untuk setiap alternatif $\left(\mathrm{V}_{\mathrm{i}}\right)$ diberikan sebagai berikut:

$$
V_{i}=\sum_{j=1}^{n} W_{j} r_{i j}
$$

$$
\begin{aligned}
& \text { Dimana: } \\
& \mathrm{Vi}=\text { Nilai Preferensi } \\
& \mathrm{Wj}=\text { Bobot ranking } \\
& \mathrm{Rij}=\text { Rating kinerja ternormalisasi }
\end{aligned}
$$

Hasil akhir diperoleh dari proses perankingan yaitu penjumlahan dari perkalian matriks ternormalisasi $\mathrm{R}$ dengan vektor bobot sehingga diperoleh nilai terbesar yang dipilih sebagai alternatif terbaik (Ai) sebagai solusi.

\section{HASIL DAN PEMBAHASAN}

\section{A. Analisis Kebutuhan Input}

Tahapan ini selanjutnya pada proses pembuatan sistem pendukung keputusan yaitu basis pengetahuan yang berarti memasukan kriteria-kriteria yang dibutuhkan sistem. Didalam penyeleksian beasiswa dengan mengunakan metode Fuzzy Multiple Attribute Decision Making (FMADM) dengan metode Simple Additive Weighting (SAW) diperlukan kriteria-kriteria dan bobot untuk melakukan perhitungan penyeleksian beasiswa, sehingga didapat alternatif terbaik. Dalam metode FMADM dengan metode SAW terdapat kriteria yang dibutuhkan untuk menentukan siapa yang akan terseleksi sebagai penerima beasiswa. Kuesioner ditujukan untuk orang tua yang akan dan sedang menyekolahkan anaknya di sekolah dasar, sebanyak 10 orang. Variabel yang dibutuhkan adalah kurikulum, biaya, dan fasilitas.

\section{B. Analisis Kebutuhan Output}

Keluaran yang dihasilkan dari penelitian ini adalah sebuah alternatif yang memiliki nilai tertinggi dibandingkan dengan alternatif nilai yang lain. Pada penelitian ini hasil keluarannya diambil dari urutan alternatif tertinggi ke alternatif terendah. Hasil akhir yang dikeluarkan oleh program nanti berasal dari nilai setiap kriteria, karena dalam setiap kriteria memiliki nilai yang berbeda-beda. Urutan alternatif yang akan ditampilkan mulai dari alternatif tertinggi ke alternatif terendah. Alternatif yang dimaksud adalah sekolah dasar.

\section{Perancangan Sistem FMADM}

Penilaian dilakukan dengan melihat nilai-nilai terhadap indikator yaitu jumlah penghasilan orangtua, usia, semester, jumlah tanggungan orangtua, jumlah saudara kandung, dan nilai IPK. Selanjutnya masing-masing indikator tersebut dianggap sebagai kriteria yang akan dijadikan sebagai faktor untuk menentukan penerima beasiswa dan himpunan fuzzynya adalah Rendah, Sedang Tengah, Banyak, Tinggi. Himpunan ini kemudian diperlakukan sebagai input kedalam sistem FMADM (dalam hal ini disebut sebagai Ci). Variabel yang digunakan dalam penelitian ini adalah Jumlah penghasilan Orangtua, Usia, Semester, Jumlah tanggungan Orangtua, jumlah saudara kandung, nilai IPK dan untuk himpunan fuzzy-nya adalah Rendah, Sedang, Tengah, Banyak, Banyak, Tinggi.

\section{Kriteria yang Dibutuhkan}

\section{1) Kriteria Bobot}

Bobot dan kriteria yang dibutuhkan untuk menentukan siapa yang akan terseleksi sebagai penerima beasiswa. Adapun kriterianya adalah:

$$
\begin{aligned}
& \mathrm{C} 1=\text { Kurikulum } \\
& \mathrm{C} 2=\text { Biaya } \\
& \text { C3 }=\text { Fasilitas }
\end{aligned}
$$

Dari masing-masing bobot tersebut, maka dibuat suatu variabel-variabelnya. Dimana dari suatu variabel tersebut akan dirubah kedalam bilangan fuzzynya. Di tabel 1 merupakan masing-masing nilai bilangan fuzzy dari bobot.

TABEL I. NILAI BOBOT BILANGAN FUZZY

\begin{tabular}{|c|c|c|}
\hline No. & Nilai & Keterangan \\
\hline 1. & 1 & Banyak \\
\hline 2. & 0.8 & Tinggi \\
\hline 3. & 0.6 & Tengah \\
\hline 4. & 0.4 & Sedang \\
\hline 5. & 0.2 & Rendah \\
\hline 6. & 0 & Sangat Rendah \\
\hline
\end{tabular}

Dari tabel 1 diketahui nilai bobot bilangan fuzzy memiliki 
nilai bobot 1 keterangannya banyak, nilai bobot 0.8 keterangannya tinggi, nilai bobot 0.6 keterangannya tengah, nilai bobot 0.4 keterangannya sedang, nilai bobot 0.2 keterangannya rendah, nilai bobot 0 keterangannya sangat rendah.

2) Kriteria Kurikulum (C1)

Variabel kurikulum dikonversikan dengan bilangan fuzzy seperti pada tabel 2 .

\section{TABEL II. NILAI KURIKULUM}

\begin{tabular}{|c|c|c|}
\hline No. & Nilai & Kurikulum \\
\hline 1. & 0.75 & Tahfidz \\
\hline 2. & 0.5 & Agama dan Akhlak Mulia \\
\hline 3. & 0.25 & Ilmu Pengetahuan Umum \\
\hline
\end{tabular}

Dari tabel 2, diketahui nilai kurikulum mempunyai nilai 0.75 kurikulum 0.75 , nilai 0.5 kurikulum agama dan akhlak mulia, nilai 0.25 kurikulum ilmu pengetahuan umum.

\section{3) Kriteria Biaya (C2)}

Variabel biaya dikonversikan dengan bilangan fuzzy bisa dilihat pada tabel 3 . Tabel 3 adalah tabel yang menerangkan konversi nilai biaya terhadap mata pelajaran yang akan dan diambil.

TABEL III. NILAI BIAYA

\begin{tabular}{|c|c|c|}
\hline No. & Nilai & Jumlah Nominal (Rp) \\
\hline 1. & 0.75 & $\mathrm{X}<5,000,000$ \\
\hline 2. & 0.5 & $5,000,000-10,000,000$ \\
\hline 3. & 0.25 & $\mathrm{X} \geq 10,000,000$ \\
\hline
\end{tabular}

Dari tabel 3, terlihat bahwa nilai 0.75 jumlah nominal $<5,000,000$, nilai 0.5 jumlah nominal 5,000,000-10,000,000, nilai 0,25 jumlah nominal $>10.000 .000$

\section{4) Kriteria Fasilitas (C3)}

Variabel fasilitas dikonversikan dengan bilangan fuzzy bisa dilihat pada tabel 4. Adapun fasilitas yang akan dinilai pada penelitian ini meliputi mushola, ruangan kelas, ruangan perpustakaan, dan fasilitas lapangan olahraga, dengan nilai masing-masing bisa dilihat pada tabel 4 .

TABEL IV. NILAI FASILITAS

\begin{tabular}{|c|c|c|}
\hline No. & Nilai & Fasilitas \\
\hline 1. & 0.75 & Mushola \\
\hline 2. & 0.5 & Ruang Kelas \\
\hline 3. & 0.5 & Perpustakaan \\
\hline 4. & 0.25 & Lapangan Olahraga \\
\hline
\end{tabular}

Dari tabel IV terdapat nilai fasilitas bahwa 0.75 fasilitas mushola, 0.5 fasilitas ruang kelas, 0.5 fasilitas perpustakaan, 0.25 fasilitas lapangan olahraga.

\section{5) Penggabungan Kriteria}

Metode SAW membutuhkan proses normalisasi matriks keputusan (x) ke suatu skala yang dapat diperbandingkan dengan semua rating alternatif yang dapat dilihat pada tabel 5 .
TABEL V. Nillai AlternatiF GabUNGAN KRITERIA

\begin{tabular}{|l|l|c|c|c|}
\hline \multirow{2}{*}{ No. } & \multirow{2}{*}{ Alternatif } & \multicolumn{3}{|c|}{ Kriteria } \\
\cline { 3 - 5 } & & $\mathbf{C 1}$ & $\mathbf{C 2}$ & $\mathbf{C 3}$ \\
\hline 1. & SDIT A Insantama & 0,30 & 0,40 & 0,20 \\
\hline 2. & SDIT A At-Tauhid & 0,35 & 0,20 & 0,30 \\
\hline 3. & SDIT Albina & 0,20 & 0,35 & 0,40 \\
\hline 4. & SD Qur'an & 0,40 & 0,20 & 0,30 \\
\hline 5. & SDIT Al-Qudwah & 0,20 & 0,30 & 0,40 \\
\hline
\end{tabular}

Dilihat dari tabel 5, maka untuk rata-rata alternatif setiap kriteria pada tiap-tiap SD berbeda. Hasil untuk SDIT A Insantama memperoleh nilai 0,30, SDIT A At-Tauhid memperoleh nilai 0,29, SDIT Albina memperoleh nilai 0,305, SD Qur'an sebesar 0,31, dan terakhir adalah SDIT Al-Qudwah memperoleh nilai sebesar 0,29. Dengan hasil tersebut, maka alternatif SD Qur'an merupakan alternatif pilihan rekomendasi terbaik dikarenakan memperoleh nilai paling besar.

\section{KESIMPULAN}

Adapun kesimpulan yang dapat diambil dari penelitian ini adalah bahwa SD Islam yang menjadi rekomendasi pilihan masyarakat di Kota Pangkalpinang adalah SD Qur'an, SDIT Albina, SDIT A Insantama, SDIT A Tauhid, dan SDIT AlQudwah. Selain itu, sistem yang dibangun hanya sebagai alat bantu untuk memberikan informasi kepada user atau sebagai bahan pertimbangan dalam mengambil keputusan untuk menentukan sekolah dasar berbasis Islam.

Sistem pendukung keputusan yang dibangun bisa membantu penentuan ranking sekolah dasar berbasis Islam dari yang terfavorit berdasarkan kriteria-kriteria yang telah ditentukan, dimana nilai bobot dari masing-masing kriteria diterjemahkan dari bilangan fuzzy kedalam bentuk sebuah bilangan crips, sehingga bisa dilakukan proses perhitungan untuk mencari alternatif terbaik.

Hasil dari pertimbangan sistem merupakan perangkingan nilai tertinggi ke rendah dan nilai tertinggi merupakan hasil yang dibutuhkan sebagai bahan pertimbangan untuk menentukan sekolah dasar berbasis Islam.

\section{UCAPAN TERIMA KASIH}

Terima kasih peneliti ucapkan kepada rekan-rekan dosen yang secara langsung maupun tidak langsung membantu dalam penyelesaian penulisan jurnal ini dan tidak lupa pula peneliti ucapkan terima kasih kepada pihak Yayasan Atma Luhur yang telah mendanai penelitian ini. Serta kami ucapkan terima kasih juga kepada STMIK Bani Saleh, Bekasi, yang telah ikut andil dalam berbagi informasi dan kolaborasi antar perguruan tinggi dalam bidang penelitian.

\section{DAFTAR PUSTAKA}

[1] Ary H. Gunawan, “Sosiologi Pendidikan,” Jakarta: PT. Rineka Cipta, 2000.

[2] Suharjo, "Mengenal Pendidikan Sekolah Dasar," Jakarta: Departemen Pendidikan Nasional, 2006.

[3] Imam, Chairul, Julius Santony, Yuhandri, "Sistem Pendukung 
Keputusan Spesifikasi Biji Jagung Berkualitas Terbaik Dengan Metode Multi Attribute Utility Theory,” Jurnal Komtekinfo, vol. 5, no. 3, 2019, doi: https://doi.org/10.29165/komtekinfo.v5i2.

[4] Lestari, Ning Rahayu, "Decision Support System in Determining Outstanding Teachers in Tutoring Institution Uses the Simple Additive Weighting Method (Case Study: Tutoring Dunia Sausan Kudus),” Jurnal Transformatika, vol. 17, no. 1, 2019, doi: https://dx.doi.org/10.26623/transformatika.v17i1.1361.

[5] Turban, Efraim and Aronson, E. Jay, "Decision Support System and Intelligent System," USA, Prentice-Hall International, Inc., 1998.

[6] H. A. Pradana, B. S. Riza, M. Naseer, D. Soetarno, T. Mantoro, "The Effect of e-CRM towards Service Quality and Net Benefits using Structure Equation Modeling," in 2017 Second International Conference on Informatics and Computing (ICIC), 2017, doi: 10.1109/IAC.2017.8280535.

[7] Sri Eniyati, "Sistem Pendukung Keputusan Pengambilan Keputusan untuk Penerimaan Beasiswa dengan Metode SAW (Simple Additive Weighting)," Jurnal Teknologi Informasi Dinamika, vol. 16, no. 1, 2011.

[8] S. Kusumadewi, S. Hartati, A. Harjoko, R. Wardoyo, "Fuzzy MultiAttribute Decision Making (FMADM)," Yogyakarta: Graha Ilmu, 2006.

[9] M. Adzan and Fatkhul Amin, "Sistem Pendukung Keputusan Pemilihan Laptop dengan Metode Analytical Hierarchy Process (AHP) Berbasis Web Mobile," in Proceeding of Seminar Nasional Teknologi Informasi dan Aplikasi Komputer (SINTAK), 2019.

[10] M. Muslihudin and M. Amrullah, "MODEL DSS UNTUK MENGETAHUI TINGKAT BAHAYA ASAP KENDARAAN MENGGUNAKAN METODE FUZZY MULTIPLE ATTRIBUTE DECISION MAKING (FMADM)", Jurnal TAM, Vol. 6, Juli 2016.

[11] Hutasoit, Rotua Sihombing, A. P. Windarto, D. Hartama, Solikhun, "Sistem Pendukung Keputusan Pemilihan Guru Terbaik Pada SMK Maria Goretti Pematang Siantar Menggunakan Metode Simple Additive Weighting (SAW)," Jurnal Riset Sistem Informasi dan Teknik Informatika, vol. 1, 2016, doi: http://dx.doi.org/10.30645/jurasik.v1i1.9.

[12] Terttiaavini, Fakhry Zamzam, Mustafa Ramadhan, T. S. Saputra, "Design a Decision Support System to Evaluate the Performance of Indonesian Lecturers by Developing a Simple Additive Weighting Method," International Journal of Advanced Science and Technology, vol. 28, no. 11, 2019.

[13] Herfina, R. A. Danoe, "Implementation of Fuzzy Multiple Attribute Decision Making (FMADM) Model using Analytic Hierarchy Process (AHP) Method and ELECTRE for Prioritizing of School Management Standards," in Proceeding of IORA International Conference on Operations Research, 2017.

[14] Bay Haqi and Jonser Sinaga, "The Selection Decision Support System of Students Eligible for Scholarship with Simple Additive Weighting Method (Case: SMK Mahadhika 2 Jakarta)," in Proceeding of
International Conference on Educational Research and Innovation, ICERI 2016, 2016.

[15] Turban, Efraim, "Decision Support Systems and Intelligent Systems Edisi Bahasa Indonesia Jilid 1," Yogyakarta, Andi, 2005.

[16] F. Fitriyani, Y. Yuranda, P. Pajarini, and R. Rosmawati, "PENENTUAN BEASISWA PADA SMPN 6 PANGKALPINANG MENGGUNAKAN METODE SAW DAN FUZZY MULTI ATTRIBUTE DECISION MAKING", Jurnal RESTI, Vol. 2, No. 1, April 2018. https://doi.org/10.29207/resti.v2i1.325.

[17] B. V. Christioko, H. Indriyawati, and N. Hidayati, "FUZZY MULTIATRIBUTE DECISION MAKING (FUZZY MADM) DENGAN METODE SAW UNTUK PEMILIHAN MAHASISWA BERPRESTASI", Jurnal Transformatika, Vol. 14, No. 2, Januari 2017. http://dx.doi.org/10.26623/transformatika.v14i2.441.

[18] H. Hamidah and O. Rizan, "PEMILIHAN CALON KETUA BADAN EKSEKUTIF MAHASISWA DENGAN MENERAPKAN FMADM (FUZZY MULTIPLE ATTRIBUTE DECISION MAKING)", Jurnal Telematika, Vol. 10, No. 1, Februari 2017. http://dx.doi.org/10.35671/telematika.v10i1.488.

[19] Surtikanti, "Pengembangan Sistem Informasi Koperasi dengan Menggunakan Metode Web Based Engineering", Jurnal Informatika Universitas Pamulang, Vol. 3, No. 29, 2018.

[20] Roger S. Pressman, and Lowe, D., "Software Engineering: A Practitioner's Approach, $6^{\text {th }}$ Edition, 2000.

[21] J. A. Baba, S. Sudewi, and E. Dwiyani, "PENGEMBANGAN MODEL PENGAMBILAN KEPUTUSAN MENGGUNAKAN FUZZY MULTIPLE ATTRIBUTE DECISION MAKING UNTUK IDENTIFIKASI POTENSI KEMISKINAN DI KABUPATEN PRINGSEWU”, Jurnal TAM, Vol. 9, No. 2, Desember 2019.

[22] S. Suhada, T. Hidayatulloh, and S. Fatimah, "PENERAPAN FUZZY MADM MODEL WEIGHTED PRODUCT DALAM PENGAMBILAN KEPUTUSAN KELAYAKAN PENERIMAAN KREDIT DI BPR NUSAMBA SUKARAJA", Jurnal JUITA, Vol. 6, No. 1, Mei 2018. 10.30595/juita.v6i1.2517.

[23] M. M. Yusro and R. Wardoyo, "APLIKASI METODE FUZZY MULTIATTRIBUTE DECISION MAKING BERBASIS WEB DALAM PEMILIHAN CALON KEPALA DAERAH DI INDONESIA", Indonesian Journal of Computing and Cybernetics System, Vol.7, No. 1, Januari 2013. https://doi.org/10.22146/ijccs.3056.

[24] A. Nurzahputra, A. R. Pranata, and A. Puwinarko, "SISTEM PENDUKUNG KEPUTUSAN PEMILIHAN LINE-UP PEMAIN SEPAK BOLA MENGGUNAKAN METODE FUZZY MULTIPLE ATTRIBUTE DECISION MAKING DAN K-MEANS CLUSTERING", Jurnal JTSISKOM, Vol. 5, No. 3, Juli 2017. https://doi.org/10.14710/jtsiskom.5.3.2017.106-109. 